\title{
A New Enzyme Immunoassay for Aconitine and Its Application to Quantitative Determination of Aconitine Levels in Plasma
}

\author{
Takako TAzawa, ${ }^{a}$ Huai-qing ZhaO,${ }^{a}$ Yan Li,${ }^{a}$ Meselhy Ragab Meselhy, ${ }^{a}$ Norio NaKamura, ${ }^{a}$ \\ Teruaki AKAo, ${ }^{b}$ and Masao HATTORI ${ }^{*, a}$ \\ ${ }^{a}$ Department of Metabolic Engineering, Institute of Natural Medicine, Toyama Medical and Pharmaceutical University; \\ and ${ }^{b}$ Department of Enzymatic Physiology, Faculty of Pharmaceutical Sciences, Toyama Medical and Pharmaceutical \\ University; 2630 Sugitani, Toyama 930-0194, Japan. Received April 9, 2003; accepted May 19, 2003
}

\begin{abstract}
A reliable enzyme immunoassay (EIA) method was developed for quantitative determination of aconitine with high sensitivity and specificity. The bovine serum albumin (BSA)- and $\beta$-galactosidase ( $\beta$-Gal) conjugates as immunogens and enzyme-labeled antigens were prepared by coupling of their proteins with succinic acid (short chain length; $n=2$, where $n$ represents the number of methylene units) and hexadecanedioic acid (long chain length; $n=14$ ) hemiesters of benzoylaconine through the respective $N$-hydroxysuccinimide esters as intermediates. Two types of the BSA-conjugates with short and long chains were repeatedly injected into rabbits to obtain anti-aconitine antisera (As1 and As2, respectively). All combinations of $\beta$-Gal-labeled antigens LAg1 $(n=2)$ and LAg2 $(n=14)$ with antisera As1 $(n=2)$ and As2 $(n=14)$ showed high sensitivity to aconitine in a range of $0.1-1.0$ ng. Although the combination of LAg2 $(n=14)$ with antiserum As1 $(n=2)$ showed high specificity to aconitine, the combination of LAg2 $(n=14)$ and As2 $(n=14)$ was highly specific to both aconitine and mesaconitine. When aconitine was intravenously administered to rats, the aconitine concentration in their plasma remarkably decreased within the first $60 \mathrm{~min}$, and then gradually declined, suggesting a two-compartment pharmacokinetic model in $\left(V_{\mathrm{c}} 0.41 \pm 0.09 \mathrm{l} / \mathrm{kg}, V_{\mathrm{dss}} 1.7 \pm 0.4 \mathrm{l} / \mathrm{kg}, C L_{\text {tot }} 10 \pm 2 \mathrm{ml} / \mathrm{min} \cdot \mathrm{kg}, A U C_{0-4800} 2055 \pm 294.3 \mathrm{ng} \cdot \mathrm{min} / \mathrm{ml}\right)$. Following oral administration of aconitine to rats at two doses of 0.1 and $1.0 \mathrm{mg} / \mathrm{kg} \mathrm{b.w.}$, the maximum plasma concentrations $\left(C_{\max }\right)$ were $0.73 \pm 0.08$ and $3.3 \pm 0.6 \mathrm{ng} / \mathrm{ml}$ at times of $45 \pm 9$ and $150 \pm 52 \mathrm{~min}$, respectively, and the $A U C_{0-1440}$ values were $130 \pm 4$ and $1600 \pm 270 \mathrm{ng} \cdot \mathrm{min} / \mathrm{ml}$. The bioavailability $(F)$ of aconitine was determined to be 0.013 , where only $1.3 \%$ of the aconitine administered orally was absorbed into the body fluid.
\end{abstract}

Key words aconitine; enzyme immunoassay; disposition

The crude drug aconite ("bushi" in Japanese) is derived from the roots of certain Aconitum species (Ranunculaceae), which are widely distributed both in China and Japan. The drug is highly toxic, but is frequently used as a component of many prescriptions used in traditional Chinese medicine, and has analgesic, anti-inflammatory, cardiovascular, and CNS activities as well as contractile effects on smooth and striated muscle. ${ }^{1)}$ Aconitine, an extremely toxic ingredient of aconite, ${ }^{1,2)}$ has pharmacological effects such as antinociceptive, ${ }^{3)}$ anti-inflammatory, ${ }^{4)}$ and positive inotropic ${ }^{5,6)}$ actions.

Pharmacokinetic and pharmacodynamic studies are necessary to evaluate the toxic and pharmacological effects of aconitine in vivo, however, they have not yet been carried out. Although many analytical methods, such as paper electrophoresis, ${ }^{7)}$ thin layer chromatography, ${ }^{8)}$ multibuffered paper chromatography, ${ }^{9)}$ gas-liquid chromatography, ${ }^{10)}$ and high performance liquid chromatography ${ }^{11)}$ were developed for aconitine alkaloids, a few are applicable to the quantitative and qualitative analysis of aconitum alkaloids present in samples from living bodies with high sensitivity and specificity. A gas chromatography-selected ion monitoring (GC/ SIM) method has been reported to detect aconitine alkaloids at ng or pg levels. ${ }^{12-14)}$ A large volume and a sophisticated pretreatment of test samples were needed to detect a specific ingredient either in blood or urine. On the other hand, enzyme immunoassay (EIA) can determine the quantity of specified substances in a small amount of blood and urine without any pretreatment with high sensitivity by utilizing the advantage of a highly selective antigen-antibody reaction. Therefore, we developed an EIA method for aconitine to rapidly and accurately analyze trace amounts in sera, and studied its disposition after intravenous and oral administration.

\section{MATERIALS AND METHODS}

Chemicals Aconitine, bovine serum albumin (BSA) and goat antiserum to rabbit IgG (Sigma Chemicals Co., St. Louis, U.S.A.); succinic acid, $N$-hydroxysuccinimide, $N, N^{\prime}$ dicyclohexylcarbodiimide (DCC) and 4-methylumbelliferyl $\beta$-D-galactoside (Nacalai Tesque Co., Kyoto, Japan); hexadecanedioic acid (Tokyo Chemicals Co., Tokyo, Japan); $\beta$ galactosidase ( $\beta$-Gal; EC 3.2.21.23) that originated from $E s$ cherichia coli (Boehringer Co., Mannheim, Germany); and Sepharose 6B (Pharmacia Biotech Co., Uppsala, Sweden) were used. Freund's incomplete adjuvant and Freund's complete adjuvant (Difco Co., Detroit, U.S.A.) were also used. Buffer A was $20 \mathrm{~mm}$ phosphate buffered saline $(\mathrm{pH} 7.3)$ containing $0.1 \% \mathrm{BSA}, 0.1 \% \mathrm{NaN}_{3}$ and $0.001 \% \mathrm{MgCl}_{2}$; and buffer $\mathrm{C}$ was $20 \mathrm{~mm}$ phosphate buffered saline ( $\mathrm{pH} 7.3$ ) containing $0.1 \% \mathrm{NaN}_{3}$ and $0.001 \% \mathrm{MgCl}_{2}$.

Animals Female Albino rabbits weighing about $2 \mathrm{~kg}$ and male Wistar rats (6 weeks old) were purchased from SLC Co. (Hamamatsu, Japan). Rats were fasted overnight and given free access to water prior to drug administration after being fed standard laboratory chow for one week.

Equipment A Yanagimoto micro melting point apparatus was used for the measurement of melting points. Specific rotations were measured with a Jasco DIP-360 automatic polarimeter at $20^{\circ} \mathrm{C}$. UV spectra were taken on a Shimadzu UV-2200 UV-VIS spectrophotometer (Kyoto, Japan) after samples were dissolved in $\mathrm{MeOH}$. IR spectra were measured 
with a Fourier transfer (FT)/IR-230 spectrometer (Jasco Co., Tokyo). ${ }^{1} \mathrm{H}$ - and ${ }^{13} \mathrm{C}$-NMR spectra were measured with a Varian Unitity 500 spectrometer or a Gemini 300 spectrometer, and chemical shifts are recorded in $\delta$ values. Tetramethylsilane (TMS) was used as an internal standard. Electrospray ionization mass (ESI-MS) spectra were measured with a Perkin-Elmer SCIEX API III biomolecular mass analyzer. Analytical TLC was carried out on precoated Kiesel gel $\mathrm{F}_{254}$ plates $(0.25 \mathrm{~mm}$, Merck) and the spots were detected either under UV light or after exposure to $I_{2}$. Fluorometry was performed on a Shimadzu RF-5000 spectrofluorometer.

Synthesis of Two Hemiesters of Benzoylaconine 1) Collidine $(0.12 \mathrm{ml})$ and succinic acid $(1.05 \mathrm{mmol})$ were added to a solution $(1.5 \mathrm{ml})$ of aconitine $(0.046 \mathrm{mmol}, \mathbf{1})$ in tetahydrofuran (THF), and the mixture was heated at $70^{\circ} \mathrm{C}$ with stirring for $22 \mathrm{~h}$. The reaction mixture was evaporated to dryness under reduced pressure and then purified by silica gel chromatography $\left(\mathrm{CHCl}_{3}-\mathrm{MeOH}=7: 3\right)$ to give a colorless oily compound, succinic acid hemiester of benzoylaconine (2) $\left(21.8 \mathrm{mg}, 67.7 \%\right.$ in yield from aconitine). $[\alpha]_{\mathrm{D}}$ $-1.4^{\circ}\left(c=1.7, \mathrm{CHCl}_{3}\right)$. IR $v_{\max }: 3450(\mathrm{OH}), 1720(\mathrm{C}=\mathrm{O})$, 1600, 1582, $1455(\mathrm{Ph}) .{ }^{1} \mathrm{H}-\mathrm{NMR}\left(\mathrm{CDCl}_{3}\right): \delta 1.11(3 \mathrm{H}, \mathrm{t}$, $J=7.0 \mathrm{~Hz}$ ), 3.17, 3.28, 3.30, 3.77 (each $3 \mathrm{H}, \mathrm{s}, \mathrm{OMe} \times 4), 3.34$ $(1 \mathrm{H}, \mathrm{d}, J=5.5 \mathrm{~Hz}, \mathrm{H}-16), 4.87(1 \mathrm{H}, \mathrm{d}, J=5.5 \mathrm{~Hz}, \mathrm{H}-14), 2.61$, 1.75 (each $\left.2 \mathrm{H}, \mathrm{t}, J=7.5 \mathrm{~Hz}, \mathrm{OCOC}_{2}\right)$. Atmospheric pressure ionization (API)-MS (positive) $\mathrm{m} / z: 704[\mathrm{M}+\mathrm{H}]^{+}$; (negative) $\mathrm{m} / \mathrm{z}: 702[\mathrm{M}-\mathrm{H}]^{-}$.

2) Collidine $(0.05 \mathrm{ml})$ and hexadecanedioic acid $(0.33$ mmol) were added to $0.5 \mathrm{ml}$ of THF containing $0.019 \mathrm{mmol}$ aconitine, and the mixture was stirred for $5 \mathrm{~h}$ at $70^{\circ} \mathrm{C}$. The reaction mixture was evaporated to dryness under reduced pressure, and then purified by silica gel chromatography $\left(\mathrm{CHCl}_{3}-\mathrm{MeOH}=8: 2\right)$ to give a colorless oily compound, hexadecanedioic acid hemiesters of benzoylaconine (3) (14.2 $\mathrm{mg}, 85.5 \%$ in yield). $[\alpha]_{\mathrm{D}}+4.0^{\circ}\left(c=0.7, \mathrm{CHCl}_{3}\right)$. IR $v_{\max }$ : $3482(\mathrm{OH}), 1722(\mathrm{C}=\mathrm{O}), 1606,1582,1450(\mathrm{Ph}) .{ }^{1} \mathrm{H}-\mathrm{NMR}$ $\left(\mathrm{CDCl}_{3}\right): \delta 1.12(3 \mathrm{H}, \mathrm{t}, J=7.0 \mathrm{~Hz}), 3.17,3.28,3.30,3.77$ (each $3 \mathrm{H}, \mathrm{s}, \mathrm{OMe} \times 4), 3.33(1 \mathrm{H}, \mathrm{d}, J=6.0 \mathrm{~Hz}, \mathrm{H}-16), 4.87$ $(1 \mathrm{H}, \mathrm{d}, J=5.5 \mathrm{~Hz}, \mathrm{H}-14), 2.35,1.65$ (each $2 \mathrm{H}, \mathrm{t}, J=7.5 \mathrm{~Hz}$, OCOC $\underline{H}_{2}$ ). API-MS (positive) $m / z: 872[\mathrm{M}+\mathrm{H}]^{+}$; (negative) $m / z: 870[\mathrm{M}-\mathrm{H}]^{-}$.

Synthesis of $\mathbf{N}$-Hydroxysuccinimide Esters of 2 and 3 Compounds $2(0.12 \mathrm{mmol})$ and $3(0.027 \mathrm{mmol})$ dissolved in $\mathrm{CH}_{2} \mathrm{Cl}_{2}(3 \mathrm{ml})$ were separately treated with $N$-hydroxysuccinimide $(0.19 \mathrm{mmol})$ and DCC $(0.19 \mathrm{mmol})$ with stirring at room temperature for $24 \mathrm{~h}$. The reaction mixtures were filtered, concentrated and then subjected to silica gel chromatography $\left(\mathrm{CHCl}_{3}-\mathrm{MeOH}=19: 1\right)$ to give the respective succinimidyl esters 4 (61.5 mg, $64.9 \%$ in yield) and $\mathbf{5}$ (17.2 $\mathrm{mg}, 65.9 \%$ in yield) as oily substances.

Compound 4: $[\alpha]_{\mathrm{D}}-0.5^{\circ}\left(c=0.8, \mathrm{CHCl}_{3}\right)$. IR $v_{\max }: 3480$ $(\mathrm{OH}), 1780,1720,1715,1658(\mathrm{C}=\mathrm{O}), 1600,1582,1455$ (Ph). ${ }^{1} \mathrm{H}-\mathrm{NMR}\left(\mathrm{CDCl}_{3}\right): \delta 1.14(3 \mathrm{H}, \mathrm{t}, J=7.0 \mathrm{~Hz}), 3.19,3.28$, 3.30, $3.76($ each $3 \mathrm{H}, \mathrm{s}, \mathrm{OMe} \times 4), 3.14(1 \mathrm{H}, \mathrm{d}, J=6.0 \mathrm{~Hz}, \mathrm{H}-$ 16), 4.89 (1H, d, $J=5.5 \mathrm{~Hz}, \mathrm{H}-14), 2.86$ (4H, s, succinimidyl $\mathrm{C}_{2}$ ).

Compound 5: $[\alpha]_{\mathrm{D}}-1.4^{\circ}\left(c=1.7, \mathrm{CHCl}_{3}\right)$. IR $v_{\max }: 3450$ $(\mathrm{OH}), 1720(\mathrm{C}=\mathrm{O}), 1600,1582,1455(\mathrm{Ph}) .{ }^{1} \mathrm{H}-\mathrm{NMR}$ $\left(\mathrm{CDCl}_{3}\right): \delta 1.22(3 \mathrm{H}, \mathrm{t}, J=7.0 \mathrm{~Hz}), 3.22,3.28,3.29,3.76$ (each $3 \mathrm{H}, \mathrm{s}, \mathrm{OMe} \times 4), 4.91(1 \mathrm{H}, \mathrm{d}, J=5.5 \mathrm{~Hz}, \mathrm{H}-14), 4.89$ $(1 \mathrm{H}, \mathrm{d}, J=5.5 \mathrm{~Hz}, \mathrm{H}-14), 2.85\left(4 \mathrm{H}\right.$, s, succinimidyl $\left.\underline{\mathrm{C}}_{2}\right)$.
Preparation of BSA Conjugates $(6, n=2 ; 7, n=14)$ Succinimidyl ester $4(17.6 \mu \mathrm{mol})$ in $0.2 \mathrm{ml}$ of pyridine was added to BSA $(0.61 \mu \mathrm{mol})$ in $3 \mathrm{ml}$ of phosphate buffer $(\mathrm{pH}$ 7.3). The mixture was stirred for $24 \mathrm{~h}$ at $4{ }^{\circ} \mathrm{C}$, and successively dialyzed for one week against $10 \%, 5 \%, 2.5 \%$ pyridine $-\mathrm{H}_{2} \mathrm{O}$ and $\mathrm{H}_{2} \mathrm{O}$, and then lyophilized in vacuo to give a BSA conjugate Ig1 (6). Similarly, succinimidyl ester 5 (6.7 $\mu \mathrm{mol})$ in $0.2 \mathrm{ml}$ pyridine and BSA $(0.23 \mu \mathrm{mol})$ in $3 \mathrm{ml}$ of phosphate buffer $(\mathrm{pH}$ 7.3) were incubated under the above conditions to give a BSA conjugate Ig2 (7).

Preparation of $\beta$-Gal Conjugates $(8, n=2 ; 9, n=14) \quad$ A $\beta$-Gal conjugate $\operatorname{LAg} 1 \quad(n=2)$ was prepared as follows: $100 \mu \mathrm{l}$ of 4 (3.5 mg in $5 \mathrm{ml}$ dioxane) with $1.0 \mathrm{ml}$ of a solution of $\beta$-galactosidase $(4.5 \mathrm{mg}$ in $1.0 \mathrm{ml}$ phosphate buffer, $\mathrm{pH}$ 7.3) were mixed and kept for $48 \mathrm{~h}$ at $4{ }^{\circ} \mathrm{C}$. The reaction mixture was applied to a column of Sepharose 6B (i.d. $1.5 \times 35$ $\mathrm{cm})$ and the column was eluted with buffer $A$ to collect the fractions. Each fraction was monitored by $\beta$-galactosidase activity and tubes containing a $\beta$-Gal conjugate LAg1 (8, $n=2$ ) were stored under $4{ }^{\circ} \mathrm{C}$. Similarly, a mixture containing $100 \mu \mathrm{l}$ of a solution of $5(2.7 \mathrm{mg}$ in $5 \mathrm{ml}$ of dioxane $)$ and 1.0 $\mathrm{ml}$ of a $\beta$-galactosidase solution $(3.2 \mathrm{mg}$ in $1.0 \mathrm{ml}$ of phosphate buffer, $\mathrm{pH} 7.3)$ was kept at $4{ }^{\circ} \mathrm{C}$ for $48 \mathrm{~h}$. The products were purified by Sepharose $6 \mathrm{~B}$ (i.d. $1.5 \times 35 \mathrm{~cm}$ ) with buffer $\mathrm{A}$, and stored as a $\beta$-Gal conjugate $\operatorname{LAg} 2(\mathbf{9}, n=14)$ under $4^{\circ} \mathrm{C}$.

Measurement of Numbers of the Hapten Bound to a BSA Molecule The BSA concentration was determined by the Lowry's method, ${ }^{15)}$ and the quantity of amino groups in the BSA molecule was measured by Habeeb's method. ${ }^{16)}$

Measurement of $\boldsymbol{\beta}$-Galactosidase Activity To measure $\beta$-D-galactosidase activity of $\beta$-galactosidase-labeled antigens (LAg1 and LAg2), a 1000-fold diluted solution of the labeled antigen $(25 \mu \mathrm{l})$ was incubated with $0.1 \mathrm{~mm}$ 4-methylumbelliferyl $\beta$-D-galactoside $(150 \mu \mathrm{l})$ for $30 \mathrm{~min}$ at $30^{\circ} \mathrm{C}$ and then the reaction was stopped by addition of $100 \mathrm{~mm}$ glycine-NaOH buffer, $\mathrm{pH} 10.3$ (4 ml). The product, 4-methylumbelliferone, was spectrofluorometrically measured at wavelengths of $365 \mathrm{~nm}$ (excitation) and $448 \mathrm{~nm}$ (emission).

Preparation of Antisera (As1 and As2) to Aconitine Each $2 \mathrm{mg}$ BSA conjugate dissolved (Ig1 or Ig2) in sterile saline $(2 \mathrm{ml})$ was emulsified with adjuvant complete Freund $(3 \mathrm{ml})$ to give an emulsion. The emulsion was administered to three rabbits by subcutaneous injection once every two weeks for three months and twice for an additional month. The entire blood volume was collected after the final injection and centrifuged at $1000 \times \boldsymbol{g}$ for $15 \mathrm{~min}$ to give the respective sera As1 and As2, which were stored at $-20^{\circ}$ for EIA experiments.

EIA Procedure Samples or standard solutions containing various amounts of aconitine were incubated with an antiserum $(50 \mu \mathrm{l})$ and $10^{3}$-fold diluted $\beta$-Gal conjugate $(25 \mu \mathrm{l})$ at room temperature for $2 \mathrm{~h}$. Ten fold diluted goat anti-rabbit $\operatorname{IgG}(20 \mu \mathrm{l})$ and 100-fold diluted normal rabbit serum $(20 \mu \mathrm{l})$ were then added to the reaction mixture. The mixture was left overnight at $4{ }^{\circ} \mathrm{C}$. After addition of buffer A $(1 \mathrm{ml})$, the resulting mixture was centrifuged at $1100 \times \boldsymbol{g}$ for $15 \mathrm{~min}$ at $4{ }^{\circ} \mathrm{C}$. The supernatant was discarded, and the precipitates were washed with buffer A followed by incubation with $0.1 \mathrm{~mm} 4$-methylumbelliferyl $\beta$-D-galactoside for $30 \mathrm{~min}$ at $30^{\circ} \mathrm{C}$. The reaction was stopped by the addition of $100 \mathrm{~mm}$ 
glycine- $\mathrm{NaOH}$ buffer, $\mathrm{pH} 10.3(4 \mathrm{ml})$. The fluorescence intensity of a product (4-methylumbelliferone) was spectrofluorometrically measured at wavelengths of $365 \mathrm{~nm}$ (excitation) and $448 \mathrm{~nm}$ (emission).

Sensitivity of EIA Various concentrations of aconitine $\left(10^{-2}, 10^{-1}, 1,10,10^{2}, 10^{3}, 10^{4}, 10^{5} \mathrm{pg} /\right.$ tube $)$ in buffer A were prepared for sensitivity determination of the EIA. The binding percentage of $\beta$-Gal conjugate antigen to antibody $\left(B / B_{0}\right)$ was calculated to obtain a standard curve, where $B_{0}$ is the fluorescence intensity in the absence of aconitine and $B$ is the intensity in the presence of aconitine. The concentration of aconitine showing $50 \%$ binding was obtained from the graph.

Precision of EIA (Inter-day and Intra-day Assays) The inter-day and intra-day assays were performed on the same samples to obtain a coefficient of variance (CV) under the same conditions twice at an interval of one month and twice at an interval of $16 \mathrm{~h}$ at $4{ }^{\circ} \mathrm{C}$, respectively.

Specificity of EIA The cross-reactivity of aconitine and related compounds at various concentrations was graphically obtained and defined as follows:

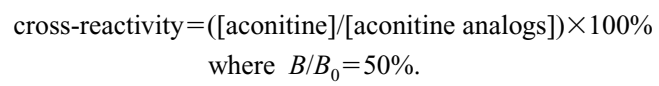

Quantitative Determination of Aconitine Levels in Plasma after Intravenous Administration to Rats Aconitine $(0.1 \mathrm{mg})$ was dissolved in DMSO $(250 \mu \mathrm{l})$ and diluted with saline to a total volume of $5 \mathrm{ml}$. A portion of the solution was injected through the tail vein to rats at a dose of $0.02 \mathrm{mg}$ aconitine $/ \mathrm{kg}$. The blood samples were collected through the tail vein at 5, 15 and $30 \mathrm{~min}$, and then 1, 2, 4, 6 and $8 \mathrm{~h}$ after intravenous administration. The samples were centrifuged at $1100 \times \boldsymbol{g}$ for $15 \mathrm{~min}$ to give the respective plasma samples. The plasma and 10 -fold diluted plasma ( $5 \mu \mathrm{l})$ were used for EIA to determine aconitine levels. A standard calibration curve ranging from $0.1-1000 \mathrm{pg}$ aconitine/tube was prepared in the presence of plasma from conventional rats.

Quantitative Determination of Aconitine Levels in Plasma after Oral Administration to Rats Aconitine
$(0.01 \mathrm{mg} / \mathrm{ml})$ dissolved in DMSO- $\mathrm{H}_{2} \mathrm{O}(1: 19)$ was orally administered to four rats at a dose of $0.1 \mathrm{mg} / \mathrm{kg}$. The blood samples were repeatedly collected through the tail vein at 5 , 15 and $30 \mathrm{~min}$, and then $1,2,4,6$ and $8 \mathrm{~h}$ after oral administration, and centrifuged at $1100 \times \boldsymbol{g}$ for $15 \mathrm{~min}$ at $4{ }^{\circ} \mathrm{C}$ to give the respective plasma samples. The plasma $(5 \mu \mathrm{l})$ was subjected to quantitative determination of aconitine by EIA.

\section{RESULTS}

Preparation of Immunogens, Enzyme-Labeled Antigens, and Anti-aconitine Antisera Dicarboxylic acid hemiesters of benzoylaconine were prepared by ester-exchanging reaction of an acetyl group at C-8 of aconitine (1) with dicarboxylic acids possessing different chain lengths, such as butanedioic acid (short chain, $n=2$ ) and hexadecanedioic acid (long chain, $n=14$ ) in the presence of collidine in THF (Fig. 1). These hemiesters $(\mathbf{2}, \mathbf{3})$ were identified by ${ }^{1} \mathrm{H}-$ NMR, where an acetyl signal ( $\delta 1.39)$ at C-8 in aconitine (1) disappeared, and instead, methylene signals that originated from the dicarbonic acids appeared. The hemiesters $(2, \mathbf{3})$ of benzoylaconine were then treated with $N$-hydroxysuccinimide (NHS) and $N, N^{\prime}$-dicyclohexyl carbodiimide (DCC) to give $N$-hydroxysuccinimide esters $\mathbf{4}$ and $\mathbf{5}$, respectively. The structures of the products were confirmed by the presence of a characteristic proton signal of a succinimidyl group at $\delta_{\mathrm{H}}$ $2.85-2.86(4 \mathrm{H})$ in the ${ }^{1} \mathrm{H}-\mathrm{NMR}$ spectra. The enzyme-labeled antigens were prepared by condensation of $\beta$-galactosidase with $N$-hydroxysuccinimide esters $\mathbf{4}$ and $\mathbf{5}$ at a molar ratio of 1 to 10 in phosphate buffer (pH 7.3). The products were purified by Sepharose 6B gel filtration. Similarly, the BSA conjugates as immunogens were prepared by coupling of BSA with $N$-hydroxysuccinimide esters $\mathbf{4}$ and $\mathbf{5}$ at a molar ratio of 1 to 30. The number of haptens bound to the BSA molecule was determined to be 3.0 and 4.0 in BSA conjugates 6 and 7, respectively.

By repeated subcutaneous injection of BSA conjugates 6 and 7 to rabbits, two types of antisera, $\mathrm{Ab} 1$ and $\mathrm{Ab} 2$, respectively, were obtained, and the highest binding affinity of both antisera to aconitine (1) was observed in the combination of
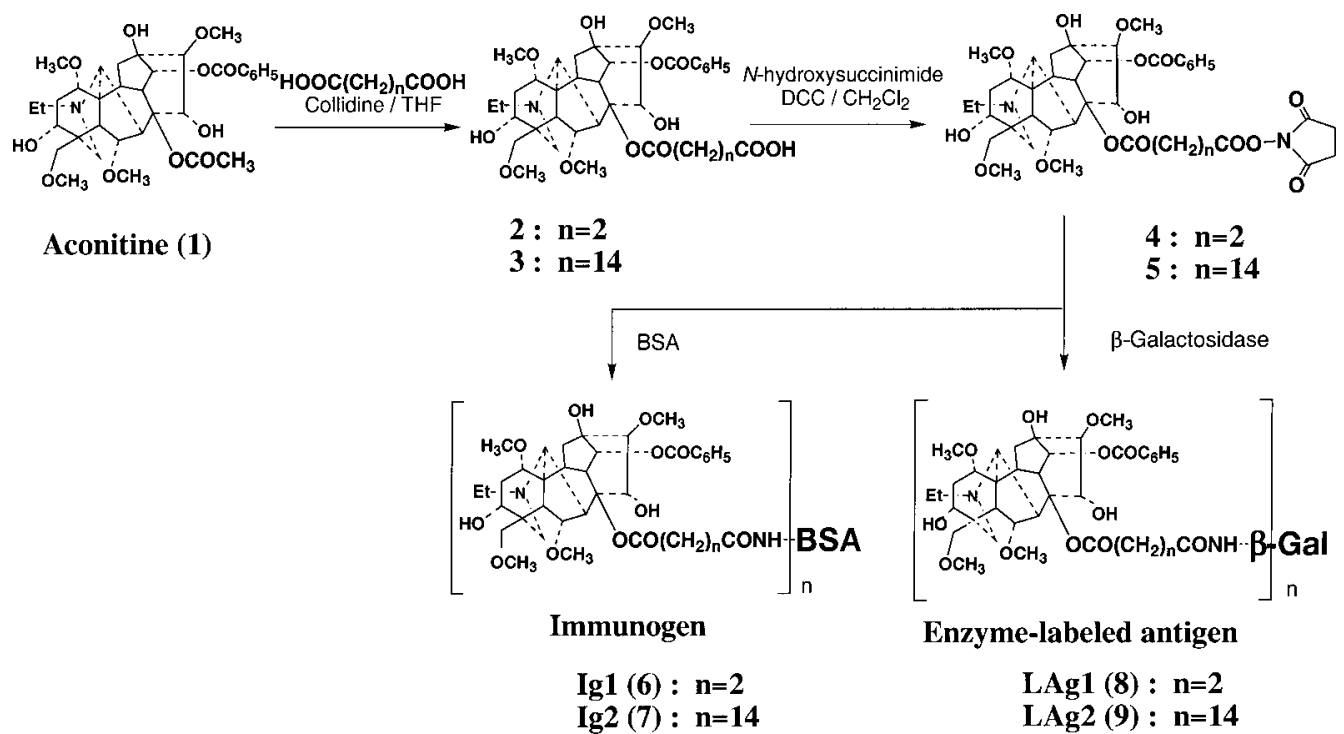

Fig. 1. Synthesis of Immunogens and Enzyme-Labeled Antigens from Aconitine 

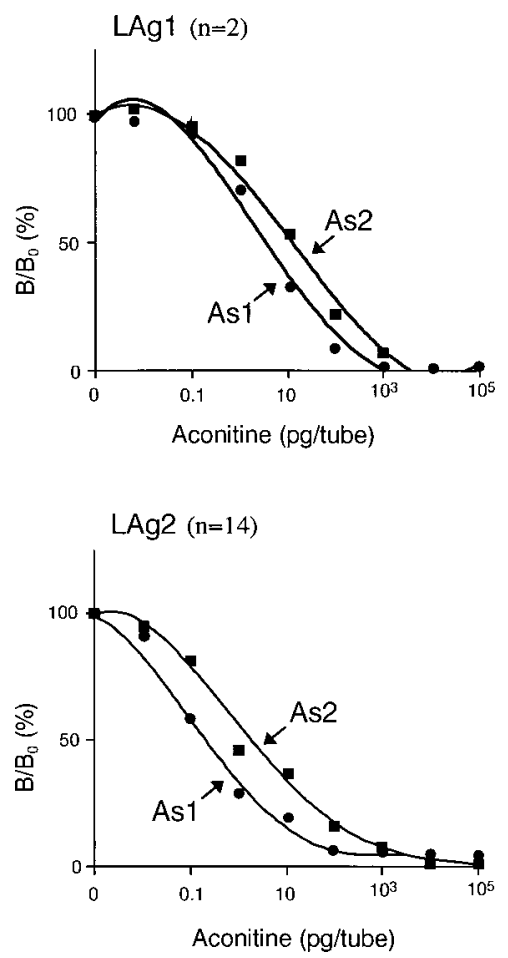

Fig. 2. Standard Curves for Aconitine in Homologous and Heterologous Combinations between Antisera and Labeled Antigens

$B=\%$ binding in the absence of aconitine, $B_{0}=\%$ binding in the presence of aconitine.

Table 1. Concentration of Aconitine (pg/tube) at $B / B_{0}=50 \%$ in Spacer Homologous and Heterologous Combinations

\begin{tabular}{|c|c|c|}
\hline \multirow{2}{*}{ Antisera } & \multicolumn{2}{|c|}{ Enzyme-labeled antigens ${ }^{a)}$} \\
\hline & LAg1 & LAg2 \\
\hline As1 & $2.03 \pm 0.51$ & $2.85 \pm 1.28$ \\
\hline As2 & $1.98 \pm 0.61$ & $2.98 \pm 1.26$ \\
\hline
\end{tabular}

a) Mean \pm S.E. $(n=3)$.

a $10^{3}$ fold-diluted serum $\mathrm{Ab} 1$ or $\mathrm{Ab} 2$ with a $10^{3}$ fold-diluted solution of $\beta$-Gal conjugate 8 or 9 in the preliminary experiment. The following experiments were then carried out with these dilutions.

Construction of EIA System Satisfactory standard curves were obtained in a range of 2.5 to $25 \mathrm{ng}$ aconitine $/ \mathrm{ml}$ $(0.1 \mathrm{pg}-1 \mathrm{ng}$ aconitine/tube) for the respective combinations of antisera and $\beta$-Gal-labeled antigens (Fig. 2). Since the concentrations of aconitine at $B / B_{0}=50 \%$ (Table 1 ) were similar in all of the combinations, no significant difference in sensitivity was observed for either spacer homologous or heterologous combination between the antisera and labeled antigens.

The intra-day and inter-day assays at three different concentrations of aconitine $(1,10,100 \mathrm{pg} /$ tube $)$ showed that the $\mathrm{CV}$ was in a range of $4.3-6.4 \%$ in the intra-day assay, but in a range of $4.8-28 \%$ in the inter-day assay, indicating that the inter-day assay was rather inferior with respect to reproducibility compared to the intra-day assay.

The standard curve of aconitine (1) in plasma was quite similar to that in buffer solutions in a range of $10-1000$

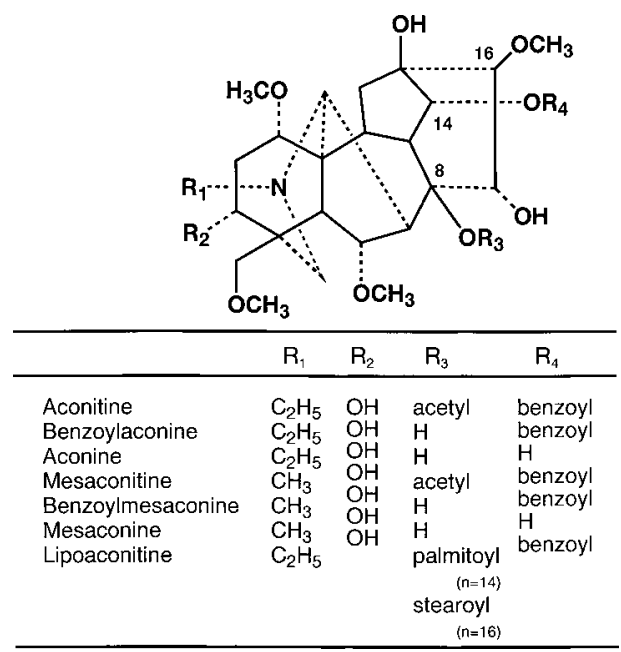

Fig. 3. Structures of Aconitine and Related Compounds

Table 2. Specificity of Antisera As1 and As2 Using a Labeled Antigen LAg2

\begin{tabular}{lcc}
\hline \hline \multirow{2}{*}{ Compound } & \multicolumn{2}{c}{ Cross reactivity $(\%)^{a)}$} \\
\cline { 2 - 3 } & As1-LAg2 & As2-LAg2 \\
\hline Aconitine & 100.0 & 100.0 \\
Benzoylaconine & 3.7 & 3.0 \\
Aconine & 0.0 & 1.6 \\
Mesaconitine & 8.0 & 156.6 \\
Benzoylmesaconine & 2.9 & 6.3 \\
Mesaconine & 0.0 & 2.7 \\
Lipoaconitine $(n=14)$ & 0.3 & 3.6 \\
Lipoaconitine $(n=16)$ & 0.6 & 0.8 \\
Neoline & 0.0 & 0.0 \\
\hline
\end{tabular}

a) Cross reactivity (\%) represents a relative concentration of aconitine, which is required to induce $50 \%$ inhibition of the binding with the antisera.

$\mathrm{pg} /$ tube (data not shown), which enables us to determine the aconitine level in plasma. At aconitine concentrations of 1.0, 10 and $100 \mathrm{pg} /$ tube, their $\mathrm{CV}$ values of variance were $2.8 \%$, $3.1 \%$ and $2.6 \%$, respectively, in the intra-day assay, and $0 \%$, $15.8 \%$ and $27.4 \%$, respectively, in the inter-day assay.

Eight aconitine-related compounds (Fig. 3) were examined in the cross reactivity experiment, which shows the relative concentrations of aconitine (1) required for $50 \%$ inhibition of binding with the antisera. The combination $\mathrm{Ag} 2-\mathrm{Ab} 1$ showed relatively high specificity to aconitine (1) but weak cross-reactivities to benzoylaconine, mesaconitine, and benzoylmesaconine (Table 2), which guarantees the quantitative determination of aconitine present in samples from the body fluid. In comparison with the cross-reactivity to these compounds in the Ag2-Ab1 combination, the combination of Ag2-Ab2 showed quite high cross-reactivity against mesaconine (156.6\% of aconitine), in which an ethyl group attached to the nitrogen atom in the aconitine skeleton is replaced with a methyl group. The combination of Ag2-Ab2 was not suitable for quantitative analysis of aconitine in a mixture of aconitine and mesaconitine. However, quantitative determination of each component may be possible using both combinations of Ag2-Ab1 and Ag2-Ab2.

Pharmacokinetics of Aconitine Following intravenous injection of aconitine to rats at a dose of $0.02 \mathrm{mg} / \mathrm{kg}$, the 


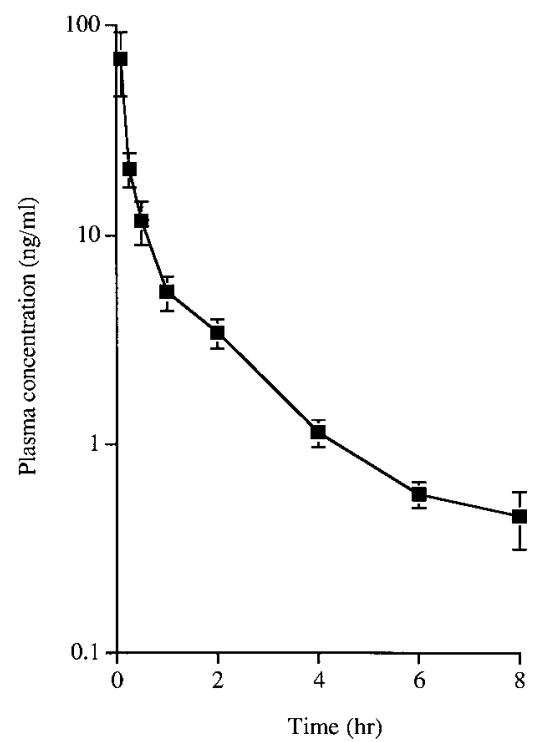

Fig. 4. Plasma Concentration-Time Curve of Aconitine after Intravenous Administration at a Dose of $0.02 \mathrm{mg}$ Aconitine/ $\mathrm{kg}$ to Rats

Table 3. Pharmacokinetic Parameters of Aconitine after $0.02 \mathrm{mg} / \mathrm{kg}$ Intravenous Administration to Rats

\begin{tabular}{lc}
\hline \hline \multicolumn{1}{c}{ Parameter } & Mean \pm S.E. \\
\hline$A(\mathrm{ng} / \mathrm{ml})$ & $56 \pm 12$ \\
$\alpha\left(\mathrm{min}^{-1}\right)$ & $0.049 \pm 0.007$ \\
$B\left(\mathrm{ng} / \mathrm{ml}^{-1}\right.$ & $3.4 \pm 0.9$ \\
$\beta\left(\mathrm{min}^{-1}\right)$ & $0.004 \pm 0.001$ \\
$t_{1 / 2 \alpha}(\mathrm{min})$ & $16 \pm 2$ \\
$t_{1 / 2 \beta}(\mathrm{min})$ & $246 \pm 91.3$ \\
$V_{\mathrm{C}}(1 / \mathrm{kg})$ & $0.41 \pm 0.09$ \\
$V d_{\mathrm{ss}}(1 / \mathrm{kg})$ & $1.7 \pm 0.4$ \\
$C L_{\text {tot }}(\mathrm{ml} / \mathrm{min} \mathrm{kg})$ & $10 \pm 2$ \\
$A U C_{0-4800}(\mathrm{ng} \mathrm{min} / \mathrm{ml})$ & $2055 \pm 294.3$ \\
\hline
\end{tabular}

Each value represents mean \pm S.E. $(n=6)$.

aconitine levels in plasma decreased rapidly within the first $1 \mathrm{~h}$ and then slowly (Fig. 4). The curve seemed to fit into the two-compartment pharmacokinetic model. Table 3 shows the pharmacokinetic parameters; $\mathrm{A}, \mathrm{B}, \alpha$, and $\beta$ were obtained from straight regression lines were $56 \pm 12 \mathrm{ng} / \mathrm{ml}, 3.4 \pm 0.9$ $\mathrm{ng} / \mathrm{ml}, 0.049 \pm 0.007 \mathrm{~min}^{-1}$, and $0.004 \pm 0.001 \mathrm{~min}^{-1}$, respectively. The area under curve $\left(A U C_{0-4800}\right)$ of $2055 \pm 294.3$ $\mathrm{ng} \cdot \mathrm{min} / \mathrm{ml}$ was obtained from a trapezoid area.

After oral administration of aconitine to rats, the plasma levels were monitored by EIA (Fig. 5). At a dose of 0.1 $\mathrm{mg} / \mathrm{kg}$, the aconitine levels increased rapidly and then gradually decreased $6 \mathrm{~h}$ after administration; the plasma level reached the maximum of $0.73 \pm 0.08 \mathrm{ng} / \mathrm{ml}\left(C_{\max }\right)$ at $45 \mathrm{~min}$ after administration. On the other hand, at the higher dose of $1.0 \mathrm{mg} / \mathrm{kg}$, the plasma level reached its peak $C_{\max }(3.3 \pm 0.6$ $\mathrm{ng} / \mathrm{ml}$ ) at $150 \mathrm{~min}$ and then decreased slowly. The $A U C_{0-1440}$ values were $130 \pm 4,1600 \pm 270 \mathrm{ng} \cdot \mathrm{min} / \mathrm{ml}$ after administration at doses of 0.1 and $1.0 \mathrm{mg}$ aconitine $/ \mathrm{kg}$, respectively, the ratio being $1: 12.3$ (Table 4 ). The bioavailability $(F)$ of orally administered aconitine was calculated to be 0.013 .

\section{DISCUSSION}

Since Kitagawa et al. reported that an acetyl group at the

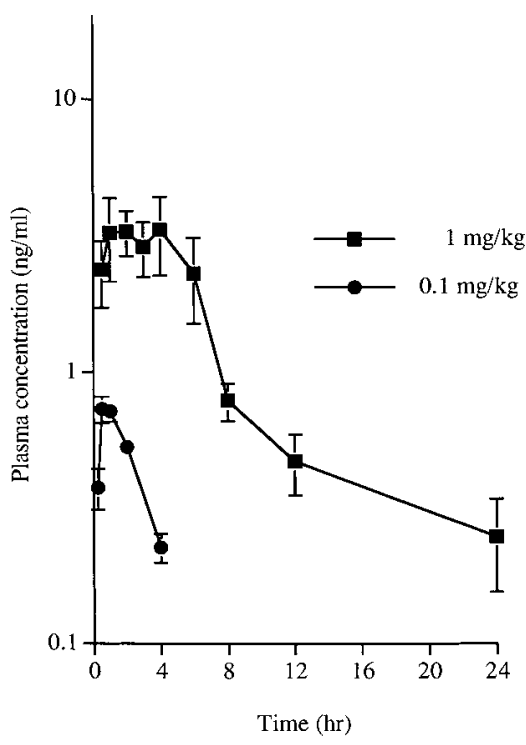

Fig. 5. Plasma Concentration-Time Curves of Aconitine after Oral Administration at Doses of 0.1 and $1.0 \mathrm{mg}$ Aconitine $/ \mathrm{kg}$

Table 4. Pharmacokinetic Parameters for 1.0 and $0.1 \mathrm{mg} / \mathrm{kg}$ Oral Administration of Aconitine to Rats

\begin{tabular}{cccc}
\hline \hline $\begin{array}{c}\text { Aconitine } \\
\text { Dose }\end{array}$ & $\begin{array}{c}C_{\max } \\
(\mathrm{ng} / \mathrm{ml})\end{array}$ & $\begin{array}{c}t_{\max } \\
(\min )\end{array}$ & $\begin{array}{c}A U C_{0-1440} \\
(\mathrm{ng} \mathrm{min} / \mathrm{ml})\end{array}$ \\
\hline $0.1 \mathrm{mg} / \mathrm{kg}$ & $0.73 \pm 0.08$ & $45 \pm 9$ & $130 \pm 4$ \\
$1.0 \mathrm{mg} / \mathrm{kg}$ & $3.3 \pm 0.6$ & $150 \pm 52$ & $1600 \pm 270$ \\
\hline
\end{tabular}

Each point represents the mean \pm S.E. $(n=4)$.

C-8 position of aconitine was easily exchanged with a variety of fatty acids to give lipoaconitine during traditional drugprocessing, ${ }^{17)}$ and we found that aconitine was converted to lipoaconitine consisting of bacterial fatty acids by incubation with intestinal bacteria, ${ }^{18}$ we applied this unique reaction to prepare an immunogen and an enzyme-labeled antigen for development of an EIA for aconitine. A short-chain or longchain dicarboxylic acid was introduced to an aconitine molecule as a spacer, which enables one to link aconitine as a hapten to a large molecule of protein. Then, aconitine derivatives 2 and $\mathbf{3}$ possessing short ( $n=2$ in Fig. 1) and long chains $(n=14)$ at $\mathrm{C}-8$, respectively, were coupled with BSA and $\beta$-Gal through their $N$-hydroxysuccinimidyl ester intermediates.

Generally, a heterologous combination between an immunogen (BSA-conjugate) and an enzyme-labeled antigen ( $\beta$-Gal conjugate), where a hapten and a protein are linked through different spacers in length, shows higher sensitivity and reproducibility than a homologous combination. Heikal et $a l .{ }^{19)}$ reported that relatively high sensitivity was observed for the heterologous combination between the $\beta$-Gal conjugate with a short spacer and the BSA conjugate with a long spacer in their experiments with paeonimetabolin I, a major metabolite from paeoniflorin produced by intestinal bacteria. However, in the present experiment, no appreciable difference in sensitivity due to the length of spacers was observed. The aconitine concentrations determined by the respective combinations at $B / B_{0} 50 \%$ were in a range of $2.0-3.0 \pm$ $0.5-1.3 \mathrm{pg} /$ tube with a small standard deviation. 
In the cross-reactivity experiment, the combination of Ag2-Ab1 showed relatively high specificity to aconitine. However, the combination of $\mathrm{Ag} 2-\mathrm{Ab} 2$ showed an extremely high cross-reactivity to mesaconitine $(156.6 \%)$. It is interesting that lipoaconitine showed no appreciable cross-reactivity to aconitine with antisera $\mathrm{Ab} 1$ and $\mathrm{Ab} 2$ though these antisera had been prepared with lipoaconitine analogs.

The EIA system developed in this experiment was quite sensitive to aconitine in a range of $0.1 \mathrm{pg}-1.0 \mathrm{ng}$, which is the most sensitive among the reported methods GC/SIM ${ }^{12}$ ) and LC-frit-FAB-MS, ${ }^{14)}$ ranges of $100 \mathrm{pg}-7.5 \mathrm{ng}$ and 5$500 \mathrm{pg}$, respectively). In addition, since no pretreatment of samples from living bodies was not necessary in our EIA method, $10 \mu \mathrm{l}$ of plasma in a range of $25 \mathrm{pg} / \mathrm{ml}-250 \mathrm{ng} / \mathrm{ml}$ was enough to measure it, compared with $0.5 \mathrm{ml}$ of serum in a range of $200 \mathrm{pg} / \mathrm{ml}-15 \mathrm{ng} / \mathrm{ml}$ for the GC/SIM method and $2 \mathrm{ml}$ of blood in a range of $5-50 \mathrm{ng} / \mathrm{ml}$ with the LC-fritFAB-MS method. In this paper, the pharmacokinetics of aconitine after intravenous and oral administration to rats at low doses of $0.02 \mathrm{mg} / \mathrm{kg}$ i.v., and 0.1 and $1 \mathrm{mg} / \mathrm{kg}$ p.o., respectively, was first reported. The time course of plasma aconitine concentration after intravenous administration was well simulated by the two-compartment model, and the concentration rapidly decreased at a half life of $16 \mathrm{~min}$. After oral administration, the $A U C$ values increased proportionally to the administered dose, suggesting aconitine is readily absorbed from the rat gastrointestinal tract. However, as the late $t_{\max }(150 \mathrm{~min})$ and the broad peak during $5 \mathrm{~h}$ were observed at the high dose, it seemed to take a long time to absorb aconitine because of its low solubility in water. The systemic bioavailabilty in rats after oral administration was calculated to be extremely low (1.3\%). This low bioavailability may be due to the first-pass effect. Since aconitine (1) easily changed to lipoaconitine with a variety of fatty acid residues at the $\mathrm{C}$ -
8 position by incubation with intestinal bacteria, ${ }^{18)}$ a similar reaction may proceed in rat intestine and liver.

\section{REFERENCES}

1) Biset N. G., J. Ethnopharmacol., 4, 247-336 (1981).

2) Ameri A., Prog. Neurobiol., 56, 211-235 (1998).

3) Hikino H., Ito T., Yamada C., Sato H., Honno C., Ohizumi Y., J. Pharm. Bio-dyn., 2, 78-83 (1979).

4) Murayama M., Mori T., Bando H., Amiya T., J. Ethnopharmacol., 35, 159-164 (1991).

5) Sato H., Yamada C., Konno C., Ohizumi Y., Endo K., Hikino H., Tohoku J. Exp. Med., 128, 175-187 (1979).

6) Honerjager P., Meissner A., Naunyn-Schmiedeberg's Arch. Pharmacol., 322, 49-58 (1983).

7) Paris R. R., Dillemann G., Faugeras G., Ann. Pharm. Fr., 17, 188 199 (1959).

8) Kurosaki F., Yatsunami T., Okamoto T., Ichinohe Y., Yakugaku Zasshi, 98, 1267-1273 (1978).

9) Yoshida H., Kuwano S., Tamura T., Matsunaga Y., Takagi S., Yakugaku Zasshi, 85, 709-714 (1965).

10) Takagi S., Katagi T., Takebayashi K., Yakugaku Zasshi, 88, 1242 1244 (1968).

11) Ohta H., Seto Y., Tsunoda N., J. Chromatography B, 691, 351-356 (1997).

12) Ito K., Ohyama Y., Konishi Y., Tanaka S., Mizugaki M., Planta Med., 63, 75-79 (1997).

13) Ito K., Tanaka S., Konno S., Konishi Y., Mizugaki M., J. Chromatography $B, 714,197-203$ (1998).

14) Ohta H., Seto Y., Tsunoda N., Takahashi Y., Matsuura K., Ogasawara K., J. Chromatography B, 714, 215-221 (1998).

15) Lowry O. H., Rosebrough N. J., Farr A. L., Randall R. J., J. Biol. Chem., 193, 265-275 (1951).

16) Habeeb A. F. S. A., Anal. Biochem., 14, 328-336 (1966).

17) Kitagawa I., Chen Z.-L., Yoshihara M., Yoshikawa M., Yakugaku Zasshi, 104, 848-857 (1984).

18) Kawata Y., Ma C., Meselhy M. R., Nakamura N., Wang H., Hattori M., Namba T., Satoh K., Kuraishi Y., J. Trad. Med., 16, 15-23 (1999).

19) Heikal O. A., Kanaoka M., Akao T., Hattori M., J. Trad. Med., 14, 105-113 (1997). 